\title{
Article
}

\section{Preparation of Heteropolyacid-intercalated Layered Double Hydroxide}

\author{
Sayaka Yanagida, *Akira Nakajima, Yoshikazu Kameshima and Kiyoshi Okada \\ Department of Metallurgy \& Ceramic Science, Tokyo Institute of Technology, 2-12-1 O-okayama, Meguro-ku, Tokyo \\ 152-8552, Japan
}

(Manuscript submitted March 30, 2007; accepted June 13, 2007)

\begin{abstract}
We prepared W-based heteropolyacid (HPA)-layered double-hydroxide (LDH) composites. The effects of the intercalation process on the composite characteristics and the Keggin structure stability were then investigated. The HPA-LDH composites were prepared using ion-exchange method on $\mathrm{Zn}-\mathrm{Al}\left(\mathrm{NO}_{3}\right) \mathrm{LDH}$ and reconstruction method on $\mathrm{Mg}-\mathrm{Al}\left(\mathrm{CO}_{3}\right) \mathrm{LDH}$. In both cases, $d=1.47 \mathrm{~nm}$ spacing, indicating HPA intercalation to $\mathrm{LDH}$, was identified. $\left[\mathrm{SiW}_{12} \mathrm{O}_{40}\right]^{4-}$ was hydrolyzed into $\left[\mathrm{SiW}_{11} \mathrm{O}_{39}\right]^{8-}$ during ion change processing, thereby obtaining $\left[\mathrm{SiW}_{11} \mathrm{O}_{39}\right]^{8-}$ - $\mathrm{LDH}$ composites.
\end{abstract}

Key words: Heteropolyacids, LDH, Reconstruction, Ion-exchange

\section{Introduction}

Heteropolyacids (HPAs) have been investigated as acid catalysts.[1,2] They are also known as photocatalysts; recently, strong photo-oxidation power of W-based HPAs was reported.[3] The HPAs are highly soluble in water and in organic solvents. For that reason, they are commonly used as homogeneous catalysts. However, direct use of HPAs for photocatalytic purification presents an obstacle to their separation from treated water. Therefore, preparation of a heterogeneous catalyst system of HPAs has been investigated using host materials such as mesoporous silica and clays.[3,4]

Layered double hydroxides (LDH) are described as $\mathrm{M}^{2+}{ }_{1-x} \mathrm{M}^{3+}{ }_{x}(\mathrm{OH})_{2} \mathrm{~A}^{n-}{ }_{x / n} \cdot \mathrm{mH}_{2} \mathrm{O}$; they are composed of octahedral $\mathrm{M}^{2+}(\mathrm{OH})_{6}$ brucite-like layers and changeable interlayer anion. These materials possess a two-dimensional layer structure. The positive layer charge is controllable by changing the ratio of divalent and trivalent cations.[5] Ion-exchange method [6-8] and reconstruction method [9-11] are known as typical anion intercalation methods. Ion-exchange method is executed by merely soaking LDHs in an anion solution; reconstruction method includes heating LDHs at $500-600^{\circ} \mathrm{C}$ before soaking in an anion solution. The layered structure decomposes when $\mathrm{LDHs}$ are heated to $500-600^{\circ} \mathrm{C}$. However, the layer structure is reconstructed by soaking it in water with a proper anion. This reconstruction process is used for large anion intercalation into LDH. To date, various polyacid and heteropolyacid anions have been shown to be intercalatable into the LDH host layer.[12]

Intercalation of anions into LDHs requires a proper balance of the charge amount and size. Hu et al. prepared a composite using W-based HPA and $\mathrm{LDH}$ with lacunary Keggin anion $\left[\mathrm{SiW}_{11} \mathrm{O}_{39}\right]^{8-}$ and $\mathrm{Zn}-\mathrm{Al}\left(\mathrm{NO}_{3}\right) \mathrm{LDH}$.[13] However, Keggin-type anions such as $\left[\mathrm{PW}_{12} \mathrm{O}_{40}\right]^{3-}$ and $\left[\mathrm{SiW}_{12} \mathrm{O}_{40}\right]^{4-}$ are difficult to intercalate into the LDH layer because these anions possess a smaller negative charge and lower stability in high-pH water than lacunary 
Keggin-type anions. In water with high $\mathrm{pH}$, Keggin-type anions are commonly decomposed into lacunary Keggin ions by hydration.[14] However, intercalation-process-dependence of the stability of W-based Keggin-type anions is not well reported. For this study, we prepared $\mathrm{LDHs}$ of the $\mathrm{Mg}-\mathrm{Al}\left(\mathrm{CO}_{3}\right)$ system and $\mathrm{Zn}-\mathrm{Al}\left(\mathrm{NO}_{3}\right)$ system. In addition, HPA-LDH composites were prepared using ion-exchange method on $\mathrm{Zn}-\mathrm{Al}\left(\mathrm{NO}_{3}\right) \mathrm{LDH}$ and reconstruction method on $\mathrm{Mg}-\mathrm{Al}\left(\mathrm{CO}_{3}\right)$ LDH using $\mathrm{H}_{4} \mathrm{SiW}_{12} \mathrm{O}_{40}$. Then, the effects of intercalation process on the composite characteristics and stability of Keggin structure were investigated.

\section{Experimental}

\subsection{LDH synthesis}

All starting chemicals were of reagent grade (Wako Pure Chemical Industries Ltd., Tokyo, Japan). In this study, $\mathrm{LDHs}$ of the $\mathrm{Mg}-\mathrm{Al}\left(\mathrm{CO}_{3}\right)$ system $(\mathrm{Mg} / \mathrm{Al}=2,4)$ and $\mathrm{Zn}-\mathrm{Al}\left(\mathrm{NO}_{3}\right)$ system $(\mathrm{Zn} / \mathrm{Al}=2)$ were prepared as in previous studies.[15,16] Solutions of $\mathrm{Mg}\left(\mathrm{NO}_{3}\right)_{2} \cdot 6 \mathrm{H}_{2} \mathrm{O}$ and $\mathrm{Al}\left(\mathrm{NO}_{3}\right)_{3} \cdot 9 \mathrm{H}_{2} \mathrm{O}$ were mixed in the appropriate ratio and co-precipitated by adding mixed solutions of $\mathrm{NaOH}$ and $\mathrm{Na}_{2} \mathrm{CO}_{3}$. After mixing ( $24 \mathrm{~h}$ ), centrifuging, washing in distilled water and ethanol, and drying, $\mathrm{LDH}$ powders of the $\mathrm{Mg}-\mathrm{Al}\left(\mathrm{CO}_{3}\right)$ system were obtained.

Solutions of $\mathrm{Zn}\left(\mathrm{NO}_{3}\right)_{2} \cdot 6 \mathrm{H}_{2} \mathrm{O}$ and $\mathrm{Al}\left(\mathrm{NO}_{3}\right)_{3} \cdot 9 \mathrm{H}_{2} \mathrm{O}$ were mixed in the appropriate ratio and co-precipitated by adding mixed solutions of $\mathrm{NaOH}$ at $\mathrm{pH}$ 9.5. In this process, distilled water was used after degassing by $\mathrm{N}_{2}$ bubbling. After refluxing in $\mathrm{N}_{2}$ at $90^{\circ} \mathrm{C}$ for $18 \mathrm{~h}$, centrifuging, washing in distilled water, and drying, LDH powder of the $\mathrm{Zn}-\mathrm{Al}\left(\mathrm{NO}_{3}\right)$ system was obtained.

\subsection{Ion Exchange Method}

Ion-exchange processing and reconstruction processing were carried out using ion changed water to avoid effects of $\mathrm{CO}_{3}{ }^{2-}$. Interlayer $\mathrm{NO}_{3}{ }^{-}$in $\mathrm{LDH}$ powder of the $\mathrm{Zn}-\mathrm{Al}\left(\mathrm{NO}_{3}\right)$ system is exchanged with HPAs in a high-temperature aqueous solution.[12,17] In this work, ethylene glycol (EG) was used as a swelling agent. An aqueous solution of $\mathrm{EG}\left(\mathrm{H}_{2} \mathrm{O}: \mathrm{EG}=1: 1\right)$ was used to support interlayer space expansion. Subsequently, $\mathrm{SiW}_{12} \mathrm{O}_{40} \cdot 26 \mathrm{H}_{2} \mathrm{O}(0.20 \mathrm{~g})$ was dissolved into EG solution $\left(40 \mathrm{~cm}^{3}\right)$ and $\mathrm{LDH}(0.40 \mathrm{~g})$ was added to the solution. The mixture was stirred at $80^{\circ} \mathrm{C}$ for $2 \mathrm{~h}$, then centrifuged at $8000 \mathrm{rpm}$ for $20 \mathrm{~min}$ after cooling and washing with water. White powder was obtained after drying at $80^{\circ} \mathrm{C}$ for $24 \mathrm{~h}$. For comparison, the same procedure was carried out using water only, instead of the EG solution.

\subsection{Reconstruction method}

The LDHs of $\mathrm{Mg}-\mathrm{Al}\left(\mathrm{CO}_{3}\right)$ system were calcined at $500^{\circ} \mathrm{C}$ for $12 \mathrm{~h}$ in air, and heat-decomposed LDHs were prepared. Then $\mathrm{SiW}_{12} \mathrm{O}_{40} \cdot 26 \mathrm{H}_{2} \mathrm{O}(0.68 \mathrm{~g})$ was dissolved into water $\left(200 \mathrm{~cm}^{3}\right)$; the heat-decomposed $\mathrm{LDHs}$ were added to the solution. After stirring for $24 \mathrm{~h}, \mathrm{LDH}$ powders were separated from the solution by centrifugation ( 8000 $\mathrm{rpm}, 20 \mathrm{~min}$ ) and washed with water. White powder was obtained after drying at $80^{\circ} \mathrm{C}$ for $24 \mathrm{~h}$.

\subsection{Evaluation}

Crystalline phases of the obtained powders were evaluated using X-ray diffraction (XRD, XRD-6100; Shimadzu Corp.). The specific surface area and pore structure were evaluated using $\mathrm{N}_{2}$ adsorption and desorption isotherms at $77 \mathrm{~K}$ (Autosorb-1; Quantachrome Instruments). The specific surface area was calculated using BET method and the pore volume was obtained from the maximum amount of adsorption at a relative pressure $\left(P / P_{0}\right)$ of 0.999. The pore size distribution was calculated using BJH method with the desorption isotherms. The average pore size was calculated from the specific surface area and pore volume. The chemical compositions of the LDHs were 
analyzed for Mg, Al, and W using ICP-OES (Teledyne - Leeman Labs, USA). The infrared spectra (FT-IR 8600PC; Shimadzu Corp.) of the samples were recorded using the $\mathrm{KBr}$ disk method.

\section{Results and Discussion}

\subsection{Ion-exchange method}

Figure 1 shows XRD patterns of $\mathrm{Zn}_{2} \mathrm{Al}(\mathrm{OH})_{6}\left(\mathrm{NO}_{3}\right) \cdot 2 \mathrm{H}_{2} \mathrm{O}$, the composites prepared in the EG solution, and that in water. In the EG solution, the ion-exchange ratio between $\mathrm{NO}_{3}{ }^{-}$and HPA was higher than that in water. The LDH layer thickness and the size of the Keggin anion are reported respectively as $0.48 \mathrm{~nm}$ and $0.98 \mathrm{~nm}$. Basal spacing $(d=1.48 \mathrm{~nm}, 003)$ and $00 \mathrm{l}$ harmonics $(d=0.732 \mathrm{~nm}, \quad 006,0.486 \mathrm{~nm}, 009)$ after ion-exchange show good agreement with the sum of LDH layer thickness and Keggin anion, implying that the ion-exchange process was attained. Furthermore, 1.48-nm spacing indicated that the gallery height was $0.98 \mathrm{~nm}$. A salt-like impurity was detected as a broad peak at $1.16 \mathrm{~nm}$. Many polyacid - LDH composites show such a

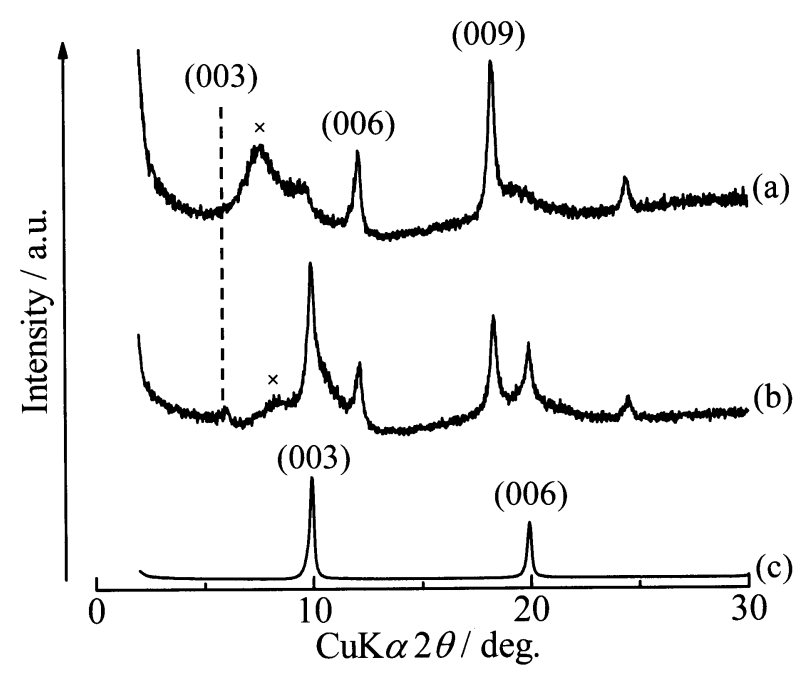

Figure 1. XRD patterns of composites prepared using ion exchange. (a) After ion exchange in EG solution. (b) After ion change in water. (c) $\mathrm{Zn}-\mathrm{Al} \mathrm{LDH}$ before ion exchange. $X$ : A salt-like impurity characteristic impurity peak.[12]

In Fig. 1, the order of peak intensity by XRD on $00 l$ harmonics is, fundamentally, $(009)>(006)>(003)$. This trend is common for both Keggin and lacunary Keggin ion intercalated LDHs such as $\mathrm{H}_{2} \mathrm{~W}_{12} \mathrm{O}_{40}-\mathrm{Zn}_{2} \mathrm{Al} \mathrm{LDH}[5]$ and $\left[\mathrm{SiW}_{11} \mathrm{O}_{40}\right]^{8-}-\mathrm{Zn}_{2} \mathrm{Al}$ LDH.[6] Therefore, the (003) peak is weaker than the (006) and (009) peaks.

Table 1 shows the result of ICP analysis. The expected atomic ratio (Al:Zn:W) calculated from the ion-exchange capacity is 1:2:1.38 if the interlayer $\mathrm{NO}_{3}^{-}$is replaced completely with $\left[\mathrm{SiW}_{11} \mathrm{O}_{39}\right]^{8-}$ in the $\mathrm{Zn}_{2} \mathrm{Al}(\mathrm{OH})_{6} \mathrm{NO}_{3}$ system. Practical values by ICP analysis were 1:1.4:0.52 for the composite using EG solution and 1:1.6:0.61 for the composite using water (Table 1), which implies that the ion-exchange capacities used for $\left[\mathrm{SiW}_{11} \mathrm{O}_{39}\right]^{8-}$ were $37 \%$ (EG solution) and $44 \%$ (water). The composite ion-exchange in water exhibited higher $\mathrm{W}$ content. However, the presence of a salt-like impurity might affect the $\mathrm{Zn}: \mathrm{Al}: \mathrm{W}$ ratio. A part of the positive layer charge might be compensated by $\mathrm{OH}^{-}$anion and the remaining $\mathrm{NO}_{3}{ }^{-}$ion.

Table 2 shows peak positions of IR spectra of the composite and $\mathrm{K}$ salt of HPAs. The composite peak positions differed from those on $\left[\mathrm{SiW}_{12} \mathrm{O}_{40}\right]^{4-}$ ion, and peak patterns resembled those of $\left[\mathrm{SiW}_{11} \mathrm{O}_{39}\right]^{8-}$ and its composite reported by $\mathrm{Hu}$ et al. The $d$-value and gallery height on $\left[\mathrm{SiW}_{11} \mathrm{O}_{39}\right]^{8-}-\mathrm{Zn}_{2} \mathrm{Al} \mathrm{LDH}$ were reported respectively as $1.452 \mathrm{~nm}$ and $0.98 \mathrm{~nm}$. Based on these results, the interlayer HPA might be lacunary $\left[\mathrm{SiW}_{11} \mathrm{O}_{39}\right]^{8-}$ or a similar species. In solution, lacunary species possess higher charges than $\left[\mathrm{SiW}_{12} \mathrm{O}_{40}\right]^{4-}$ ion. Moreover, $\left[\mathrm{SiW}_{12} \mathrm{O}_{40}\right]^{4-}$ is stable only when $\mathrm{pH}$ is less than 6 . After reflux treatment, the $\mathrm{pH}$ of the solution was around 8 . For that reason, $\left[\mathrm{SiW}_{12} \mathrm{O}_{40}\right]^{4-}$ was decomposed into $\left[\mathrm{SiW}_{11} \mathrm{O}_{39}\right]^{8-}$; then, selective intercalation occurred during the ion-exchange reaction. 
Table 1. Chemical composition of Zn-Al LDH and composites

\begin{tabular}{llll}
\hline & \multicolumn{3}{c}{ Molar ratio } \\
sample & $\mathrm{Al}$ & $\mathrm{Zn}$ & $\mathrm{W}$ \\
\hline $\mathrm{ZnAl}_{2}-\mathrm{NO}_{3} \mathrm{LDH}$ & 1.0 & 2.1 & - \\
After ion-exchange in EG solution & 1.0 & 1.4 & 0.52 \\
After ion-exchange in water & 1.0 & 1.6 & 0.61 \\
\hline
\end{tabular}

Table 2. IR peak positions of composites and HPA $\left(\mathrm{cm}^{-1}\right)$

\begin{tabular}{lllll}
\hline sample & Si-Oa & W=Od & W-Ob-W & W-Oc-W \\
\hline Zn-Al LDH composite by EG solution & 1000 & 952 & 908 & \\
Zn-Al LDH composite by water & 999 & 954 & 908 & \\
Mg-Al LDH composite $(\mathrm{Mg} / \mathrm{Al}=2)$ & 1000 & 955 & 912 & 798 \\
Mg-Al LDH composite $(\mathrm{Mg} / \mathrm{Al}=4)$ & 1000 & 954 & 908 & \\
ZnAl2-SiW11*1 & 997 & 945 & 897 & 792,728 \\
SiW12*2 & 930 & 982 & 885 & 792 \\
SiW11*2 & 1000 & 952 & 870 & 797,725 \\
\hline
\end{tabular}

${ }^{* 1} \mathrm{Hu}$ et al. $[6]{ }^{* 2} \mathrm{~K}$ salt

Table 3. Porous properties of the LDHs

\begin{tabular}{llll}
\hline & $\begin{array}{l}\text { Specific surface area } \\
\left(\mathrm{m}^{2} / \mathrm{g}\right)\end{array}$ & $\begin{array}{l}\text { Total pore volume } \\
\left(\mathrm{cm}^{3} / \mathrm{g}\right)\end{array}$ & $\begin{array}{l}\text { Average pore size } \\
(\mathrm{nm})\end{array}$ \\
\hline $\mathrm{ZnAl}{ }_{2} \mathrm{LDH}$ & 19 & 0.11 & 12 \\
$\mathrm{Zn}-\mathrm{Al} \mathrm{LDH}$ composite by EG solution & 57 & 0.12 & 4.3 \\
$\mathrm{Zn}-\mathrm{Al} \mathrm{LDH}$ composite by water & 43 & 0.11 & 5.2 \\
\hline
\end{tabular}

$$
\mathbf{M g} / \mathbf{A l}=\mathbf{2}
$$

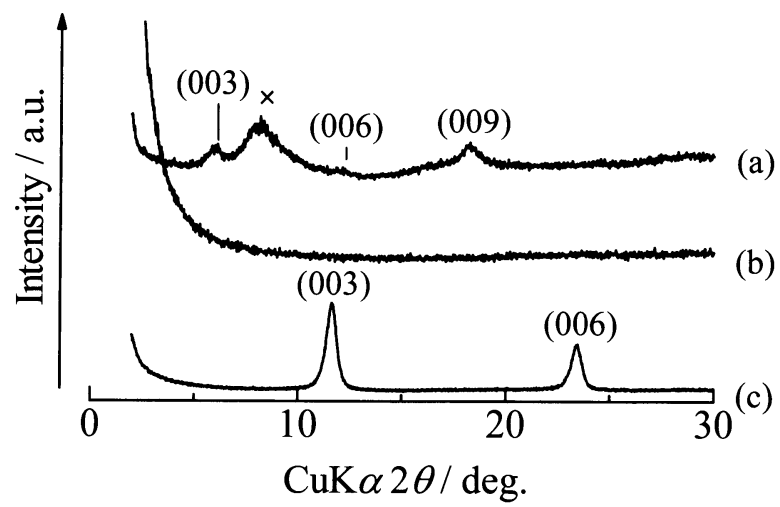

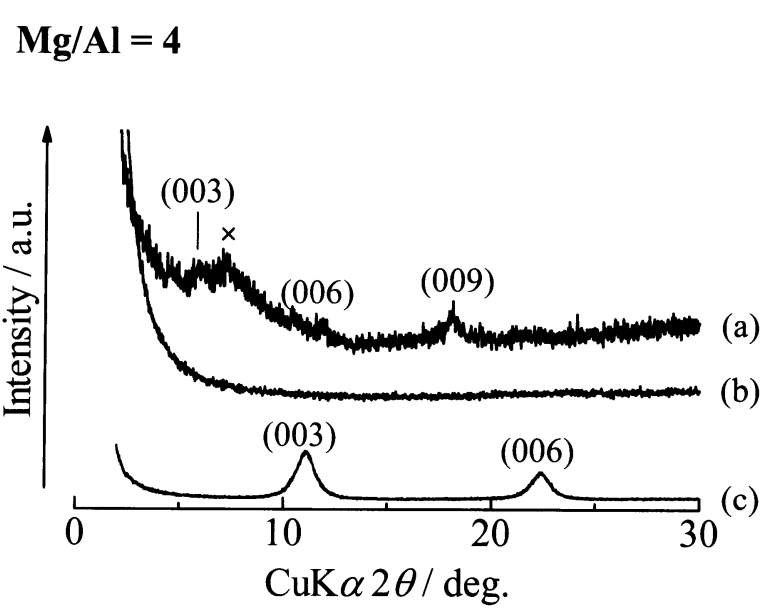

Figure 2. XRD patterns of composites prepared by reconstruction. (a) Reconstructed HPA-LDH composite. (b) Heat-decomposed LDH (c )Mg-Al- $\mathrm{CO}_{3} \mathrm{LDH}$ before heat treatment. $\mathrm{X}$ : A salt-like impurity

The specific surface area, total pore volume, and average pore size of the obtained LDHs are listed in Table 3. 
The order of the specific surface area is $\mathrm{Zn}_{2} \mathrm{Al}\left(\mathrm{NO}_{3}\right) 2 \mathrm{H}_{2} \mathrm{O}<\mathrm{HPA}-\mathrm{Zn}_{2} \mathrm{Al}$ LDH composite (ion-exchanged in water) $<\mathrm{HPA}-\mathrm{Zn}_{2} \mathrm{Al} \mathrm{LDH}$ composite (ion-exchanged in EG solution). Intercalated HPA anion worked as pillars and expanded the gallery height, thereby increasing the specific surface area.

\subsection{Reconstruction method}

Figure 2 shows XRD patterns of $\mathrm{Mg}_{2} \mathrm{Al}(\mathrm{OH})_{6}\left(\mathrm{CO}_{3}\right) \cdot 2 \mathrm{H}_{2} \mathrm{O}$ and $\mathrm{Mg}$-Al composites prepared using the reconstruction method. The layer structure of $\mathrm{Mg}-\mathrm{Al}\left(\mathrm{CO}_{3}\right) \mathrm{LDHs}$ was destroyed and their peaks were eliminated by heat treatment at $500^{\circ} \mathrm{C}$. After reconstruction, new peaks appeared. Although the peaks were broader than those of ion-exchange composites in $\mathrm{Zn}-\mathrm{Al} \mathrm{LDH}$, basal spacing $(d=1.45 \mathrm{~nm}, 003)$ and $00 l$ harmonics $(d=0.735 \mathrm{~nm}, 006$, $0.486 \mathrm{~nm}, 009)$ indicated that ion exchange was attained. A broad peak at $1.07 \mathrm{~nm}(2 \theta=8.3 \mathrm{deg})$ indicates an impurity that is commonly observed in HPA-LDH composites.

Table 4. Chemical composition of Mg-Al LDH and composites

\begin{tabular}{llll}
\hline & \multicolumn{3}{c}{ Molar ratio } \\
Sample & $\mathrm{Al}$ & $\mathrm{Mg}$ & $\mathrm{W}$ \\
\hline $\mathrm{Mg}_{2} \mathrm{Al}-\mathrm{CO}_{3} \mathrm{LDH}$ & 1.0 & 2.0 & - \\
$\mathrm{Mg}-\mathrm{Al} \mathrm{LDH}$ composite $(\mathrm{Mg} / \mathrm{Al}=2)$ & 1.0 & 1.7 & 1.12 \\
$\mathrm{Mg}_{4} \mathrm{Al}-\mathrm{CO}_{3} \mathrm{LDH}$ & 1.0 & 4.0 & - \\
$\mathrm{Mg}-\mathrm{Al} \mathrm{LDH}$ composite $(\mathrm{Mg} / \mathrm{Al}=4)$ & 1.0 & 3.3 & 0.7 \\
\hline
\end{tabular}

Table 5. Porous properties of $\mathrm{Mg}-\mathrm{Al}-\mathrm{CO}_{3} \mathrm{LDHs}$ and composites

\begin{tabular}{llll}
\hline Sample & $\begin{array}{l}\text { Specific surface area } \\
\left(\mathrm{m}^{2} / \mathrm{g}\right)\end{array}$ & $\begin{array}{l}\text { Total pore volume } \\
\left(\mathrm{cm}^{3} / \mathrm{g}\right)\end{array}$ & $\begin{array}{l}\text { Average pore size } \\
(\mathrm{nm})\end{array}$ \\
\hline $\mathrm{Mg}_{2} \mathrm{Al}-\mathrm{CO}_{3} \mathrm{LDH}$ & 130 & 1.1 & 17 \\
$\mathrm{Mg}-\mathrm{Al} \mathrm{LDH}$ composite $(\mathrm{Mg} / \mathrm{Al}=2)$ & $<1$ & 0.02 & - \\
$\mathrm{Mg}_{4} \mathrm{Al}-\mathrm{CO}_{3} \mathrm{LDH}$ & 130 & 0.32 & 4.9 \\
$\mathrm{Mg}-\mathrm{Al} \mathrm{LDH}$ composite $(\mathrm{Mg} / \mathrm{Al}=4)$ & 85 & 0.09 & 2.1 \\
\hline
\end{tabular}

Similarly to $\mathrm{Zn}-\mathrm{Al}\left(\mathrm{NO}_{3}\right) \mathrm{LDH}$, the IR spectra imply that $\left[\mathrm{SiW}_{11} \mathrm{O}_{39}\right]^{8-}$ was intercalated in this system. Table 4 shows the result of ICP elemental analysis. If reconstruction is attained completely with $\left[\mathrm{SiW}_{11} \mathrm{O}_{39}\right]^{8-}$, the ideal molar ratio (Al:Mg:W) of the $\mathrm{Mg}_{2} \mathrm{Al} \mathrm{LDH}$ system should be 1:2:1.38. In the case of the $\mathrm{Mg}_{4} \mathrm{Al}$ system, the ideal ratio is 1:4:1.38. Compared with the ICP results shown in Table 4 (1:1.7:1.1 and 1:3.3:0.7), the ion-exchange capacity used for $\left[\mathrm{SiW}_{11} \mathrm{O}_{39}\right]^{8-}$ was $81 \%$ in the case of $\mathrm{Mg}_{2} \mathrm{Al}-\mathrm{LDH}$, and $50 \%$ in the $\mathrm{Mg}_{4} \mathrm{Al}-\mathrm{LDH}$ system. The decrease of the $\mathrm{Mg} / \mathrm{Al}$ ratio before and after ion exchange indicates leaching of $\mathrm{LDH}$ by HPA. The $\mathrm{HPA}-\mathrm{Mg}_{2} \mathrm{Al}$ composite contained a larger amount of $\mathrm{W}$ than the $\mathrm{HPA}-\mathrm{Mg}_{4} \mathrm{Al}$ composite. A larger layer charge is advantageous for HPA anion intercalation. The composite prepared using the reconstruction process exhibits a lower specific surface area than the original Mg-Al $\left(\mathrm{CO}_{3}\right)$ LDHs (Table 5). Gardner et al. reported that $\mathrm{Zn}$-based LDH intercalated with a Keggin-type HPA $\left(\mathrm{H}_{2} \mathrm{~W}_{12} \mathrm{O}_{40}\right)$ is nonporous after outgassing at $70^{\circ} \mathrm{C}$.[12] They attributed this result to the poor accessibility to the interlayer space for $\mathrm{N}_{2}$ and organic substances when it is occupied by solvated Keggin anion. In the present study, the $\mathrm{Mg}_{2} \mathrm{Al}$ composite contained a larger amount of $\left[\mathrm{SiW}_{11} \mathrm{O}_{39}\right]^{8-}$ than the $\mathrm{Mg}_{4} \mathrm{Al}-\mathrm{LDH}$ 
composite and the $\mathrm{Zn}_{2} \mathrm{Al}-\mathrm{LDH}$ composite, which is one reason for the nonporous structure of the $\mathrm{Mg}_{2} \mathrm{Al}$ composite. Incomplete ion exchange might be a key factor for preparation of the porous structure. Deposition of the salt-like impurity might also signal an important effect on the result of specific surface area.

Characterization of the interlayer $\left[\mathrm{SiW}_{11} \mathrm{O}_{39}\right]^{8-}$ is carried out using XRD and IR spectra in this study. The gallery height of LDH is known to be equivalent to the interlayer polyacid size.[12,16,17] Other decomposed species of Keggin ion, e.g., $\left[\mathrm{SiW}_{9} \mathrm{O}_{34}\right]^{10-}$, are smaller than $1.0 \mathrm{~nm}$. For that reason, D-spacing should decrease less than 1.48 if these anions were intercalated. The ratio between $\mathrm{Si}$ and $\mathrm{W}$ is important information that is useful to identify the HPA structure. However, interlayer $\left[\mathrm{SiW}_{11} \mathrm{O}_{39}\right]^{8-}$ characterization by ICP analysis was almost impossible in this case because of the interference with Si contamination from the glass flask at LDH synthesis and existence of the salt-like impurity. At present, IR yields direct evidence of $\left[\mathrm{SiW}_{11} \mathrm{O}_{39}\right]^{8-}$ intercalation. Detailed characterization of intercalated ions using other spectroscopic analyses is now underway.

\section{Summary}

In this study, we prepared W-based HPA-LDH composites; the effects of intercalation process on the composite character and the stability of the Keggin structure were investigated. The HPA-LDH composites were prepared using ion-exchange method on $\mathrm{Zn}-\mathrm{Al}\left(\mathrm{NO}_{3}\right) \mathrm{LDH}(\mathrm{Zn} / \mathrm{Al}=2)$ and reconstruction method on $\mathrm{Mg}-\mathrm{Al}\left(\mathrm{CO}_{3}\right)$ LDHs $\left(\mathrm{Mg} / \mathrm{Al}=2\right.$, 4). When $\mathrm{H}_{4} \mathrm{SiW}_{12} \mathrm{O}_{40}$ was used as a starting material for HPA, intercalation of HPA was confirmed into both LDHs by XRD. Both IR and chemical analyses suggested that $\left[\mathrm{SiW}_{12} \mathrm{O}_{40}\right]^{4-}$ was hydrolyzed to $\left[\mathrm{SiW}_{11} \mathrm{O}_{39}\right]^{8-}$ during ion change.

\section{References}

1) M. Misono, Chem. Commun., 1141-1152 (2001).

2) I. V. Kozhevnikov, Chem. Rev., 98, 171-198 (1998).

3) Y. Izumi, M. Ono, M. Kitagawa, M. Yoshida, and K. Urabe, Micropor. Mater., 5, 255 (1995).

4) S. Roy, M. C. D. Mourad and M. T. Rijneveld-Ockers, Langmuir, in press.

5) A. I. Khan and Dermot O'Hare, J. Mater. Chem., 12, 3191 (2002)

6) S. Kikkawa and M. Koizumi, Mater. Res. Bull., 17, 191-198 (1982)

7) T. Kameda, T. Yoshioka, T. Mitsuhashi, M. Uchida, and A. Okuwaki, Water Research, 37, 1545-1550 (2003)

8) M. Badreddine, A. Legrouri, A. Barroug, A. De Roy, and J. P. Besse, Mater. Lett., 38, 391-395 (1999)

9) K. A. Carrado, A. Kostapapas and S. L. Suib, Solid State Ionics, 26, 77-86 (1988)

10) M. X. Reinholdt and R. J. Kirkpatrick, Chem. Mater., 18, 2567-2576 (2006)

11) S. Aisawa, S. Takahashi, W. Ogasawara, Y. Umetsu, and E. Narita, J. Solid State Chem., 162, 52-62 (2001)

12) E. Gardner and T. J. Pinnavaia, Applied Catalysis A, 167, 65-74 (1998).

13) C. Hu, Q. He, Y. Zhang, E. Wang, T. Okuhara, and M. Misono, Catalysis Today, 30, 141-146 (1996).

14) "Polyoxometalate Molecular Science" ed. J. J. Borrás-Almenar, E. Coronado, A. Müller, and M. Pope, Kluwer Academic Publishers, Dordrecht, The Netherlands, 2003, pp41-43

15) Y. Kameshima, H. Yoshizaki, A. Nakajima, and K. Okada, J. Colloid and Interface Sci., 298, 624-628 (2006).

16) T. Kwon and T. J. Pinnavaia, Chem. Mater., 1, 381-383 (1989).

17) C. Hu, Q. He, Y. Zhang, Y. Liu, Y. Zhang, T. Tang, J. Zhang, and E. Wang Chem. Commun., 121-122 (1996). 